\title{
KOCHO RATSIN: THE FIRST MACEDONIAN NATIONAL POET
}

\begin{abstract}
:
The article is devoted to Kocho Ratsin (Solev, 1908-43), the first Macedonian national poet. He published his poems under a pseudonim in honor of a girl he was unrequitedly in love with. Kocho Ratsin was also a member of Yugoslavian revolutionary movement of 1920-30s and fought for the recognition of Macedonians as a separate nation. He died during the Second World War fighting with partisan group against the Nazis. His only published collection of poems Beli Mugri ("The White Dawns", 1939) was dedicated to poverty and the plight of his nation. The main themes of his work were social injustice and protest against exploitation. Ratsin's verse is naturally linked to the tradition of Macedonian folk poetry.
\end{abstract}

\section{Keywords:}

Kocho Ratsin, Macedonian literature, social protest poetry, folklore, collection "The White Dawns."

АнНОТАЦИя: А.Г. ШЕШКЕН. «ПЕРВЫЙ НАЦИОНАЛЬНЫЙ МАКЕДОНСКИЙ ПОЭТ КОЧО РАЦИН».

Статья посвящена Кочо Рацину (Солеву, 1908-43) - первому македонскому национальному поэту. Он публиковался под псевдонимом, образованном от имени девушки, в которую был безответно влюблен. Являлся участником революционного движения Югославии 1920-30-х гг. и борцом за признание македонцев отдельным народом. Погиб во время Второй мировой войны, сражаясь в партизанском отряде против фашистов. Его единственный сборник стихов Бели мугри («Белые рассветы», 1939) был посвящен бедственному положению народа. Мотивы социальной несправедливости и протеста против эксплуатации были главными в его творчестве. Стих Рацина органично связан с традицией македонской народной поэзии.

\section{Ключевые слова:}

Кочо Рацин, македонская литература, поэзия социального протеста, фольклор, сборник «Белые рассветы».

Kocho Ratsin was born in Veles into the family of a poor artisan potter,
who was unable to provide his son with access to a systematic education. Ratsin inherited a love for the beauty of his native language from his grandfather, a singer and musician who played at rural holidays, and his mother, a well-known performer of folk songs. He was very naturally gifted, drew well, learned Russian, Czech and German, read in French, and used every opportunity to visit the library, studying works on philosophy and culture as well as historical materials related to Macedonia's past. As an individual, Ratsin was molded by 


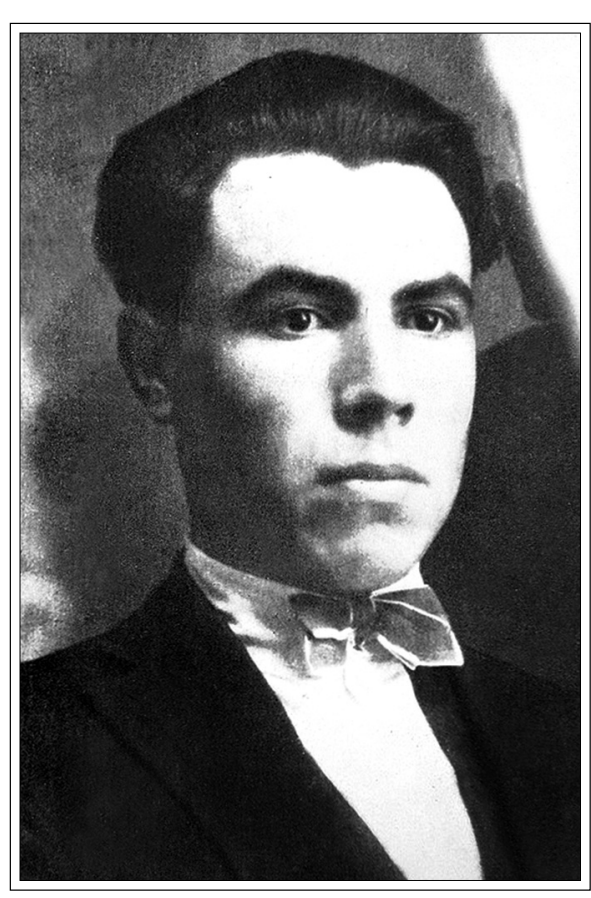

Kocho Ratsin

the country's socialist movement of the 1920s-30s. A thirst for social justice and the emergence of national literature in their native language were closely associated by the Macedonians with the struggle for national identity in the Kingdom of Serbs, Croats and Slovenes, which did not recognize it and which prohibited the official use of the Macedonian language. Ratsin was a member of the workers' movement and the editor of the illegal newspaper Iskra ("The spark," 1934), the Communist Party's press organ, published illegally in Skopye. He was arrested and imprisoned for publicly reading his revolutionary poems (1932-34). He died prematurely during the Second World War, fighting in a partisan group against the Nazis and was buried in Kichevo.

Ratsin's social origins awakened in him a desire for social justice at an early age, and predetermined the themes and ideological pathos of his early works. He identified with the movement of "social literature", whose press organs ("Criticism" and "Literature" in Zagreb, Snaga / "The Strength" in Sarayevo, Radnik / "The Worker" in Zagreb and Mladost in Belgrade) became interested in the work of the young author "of the workers" and began to publish his poetry, prose and critical articles. Ratsin's early poetry, and particularly his prose, often demonstrated a simplistic sociological view of artistic creation, its themes and problems. In the second half of the 1930s, having entered a period of creative maturity, he began to pay serious attention not only to content, but also to the artistic aspect of creativity. At first, he produced poetry, prose and criticism in the Serbian language; in those years publishing works in Macedonian was forbidden. His first collection of poems about his unrequited love for the girl Ratsa, "Anthology of Pain" (1928), remained unpublished. This was the origin of the poetic pseudonym he chose for himself, "Ratsin", that is, belonging to his beloved Ratsa.

He made his literary debut in 1928 in the journal "Criticism" with the programmatic poem Sinovij Gladi / "Sons of Hunger." It reflected the young author's intention to write on behalf of downtrodden workers ("...I have nothing... I am the son of hunger"), who were humiliated and insulted ("contempt and laughter are the rewards received from everyone"), and in whose souls hate of their oppressors is born and ripens into a protest of immense power. The early Ratsin gravitated towards expressionism, with its penchant for abstraction, baring of 
emotions, grotesque imagery, and a fantastic, "mystical" vision of the world. The motifs of "pain", "terrible scream" and "hunger" run through all of his work, undergoing changes along the way.

Ratsin's lyrics from the years 1928-33 openly called for a revolutionary reorganization of the world (Vatromet / "Fireworks"). His prose from those years [stories, excerpts from the novel Afion ("Opium" - in Serbian] was notable for its open bias, journalistic bent, social protest and satirical denunciation of the ruling class. The story U kamenolomu ("In the quarry", 1931), about the death of workers as a result of an explosion, was recognized by the magazine Literature as the winner of its short story contest.

The most fruitful and significant new period in Ratsin's creative development came after his arrest and imprisonment in a penal camp in 1934-35. Without losing its sharp ideological orientation, his poetry of the second half of the 1930s gradually departs from abstract and overly expressive images and takes on concrete national outlines. Ratsin began to write in the Macedonian language; the power of a living spoken language became the basis of his lyrics, because in the folk songs of Macedonia he caught "its prayer, the reflection of its soul and its breath".

The lyrics he produced in Macedonian during the years 1936-39 were consolidated in the collection Beli Mugri ("The White Dawns", Zagreb, 1939). For reasons of secrecy, its circulation was printed in the vicinity of Zagreb in a private printing house. The collection was distributed illegally but quickly became famous and gained recognition. The new poet was mentioned in the leftist press. It consisted of a dozen poems and two poetic cycles Elegii za tebe ("Elegies to You") and Na Struga djukyan da imam ("Would I have a workshop in Struga"), creating an image of Macedonia and its long-suffering people. The poet's gaze was drawn to people who were close and dear: a Macedonian girl who dreamed of a happy marriage but died of tuberculosis (Lenka), a peasant whose entire crop was killed by frost (Selska Maka / "Peasant Labor"), a married couple at the moment of separation, when the husband leaving for work senses that he will not return alive (Proshtevane / "Farewell"), artisans once known for their craftsmanship but now ruined (the cycle Na Struga djukyan da imam).

Approaching the pillars of national life entailed a considerable change in his poetic arsenal and a change in the lyrical hero and was reflected in the form of the poem and the nature of its genre. Ratsin uses the motifs, imagery, metaphors and epithets of folk poetry.

The poet still openly declared his ideological stance. He observed that the peasant all "his century has been working for nothing / all for someone else's barn". The sharper ideological orientation and tendentiousness of the verse helped to bring both the "object" of the lyrics (tobacco collectors, unemployed artisans, peasants working from dawn to dawn) and the author's ideas unto focus: he openly expressed and doggedly repeated his belief that the world's structures were unjust, and advocated for their change. The lyrical hero is overcome 
with love and sympathy for his native land and its people, and this colors the poet's lyrics in elegiac tones. One of the collection's cycles is called "Elegies to You". They, however, have no specific addressee. "You" is the land of Macedonia, on whose behalf the poet dreams of gaining a better and more equitable share. And although the author, as before, is waiting for the "dawn", the revolution, he clothes this expectation in poetic formulations that are close to folk poetry, using the octanarianmeter characteristic of folklore. Ratsin's technique of employing antithesis, a tradition of folk lyrics, serves to increase the ideological pathos of the verse by using this technique to the fullest extent. In the collection, epithets peculiar to folklore are widely and constantly used sindzhir zhelezni / "iron chain," solntse svetlo / "the sun is bright." gora zelena / "green forest," voda studena / "cold water," luti rani / "cruel wounds," izvori bistri / "quick springs," metaphors, personifications and repetitions.

Popular folk songs are a kind of subtext, while receiving a new interpretation. In the poem "Lenka," the words of one of the most famous songs in Macedonia, "Bilyana, the canvas was white", were taken as an epigraph. But unlike the folk song, Ratsin's young girl withered early and died of hard work. In the cycle "Would I have a workshop in Struga," the lyrical hero bitterly recalls the former wealth of the city, the gold and silver craftsmen, i.e., the times when the folk song of the same name was born. It is filled with joyful, cheerful content. In it an unnamed author sings that the workshop in Struga would help him become a rich and an enviable groom. Ratsin's lyrical hero, on the other hand, lives hand to mouth. In the creator's poetry, the motif of the anti-Turkish uprising of 1903 on St. Eliyah's Day is also developed, transformed into a symbol of eternal striving for freedom.

The poem "Diggers" in its emotions echoes Ratsin's early poetry in Serbian. It contains a protest against social oppression and glorifies the working man. In it, Ratsin refers to the "descendants of Grandfather Bogomil," the leader of the heretical religious movement, which the poet called the first carrier of the idea of social equality in Europe. On this subject, Ratsin wrote two articles: "The Bogomils" and "The Peasant Movement of the Bogomils in the Middle Ages," proving that the Macedonians have a glorious historical past, and that they contributed to the history of religious and philosophical thought in Europe.

Ratsin's collection of poetry played a special role in the development of Macedonian literature. The appearance of "The White Dawns" was the result of a long historical journey of art in Macedonia. At the same time, it was a landmark work which opened the way for the future development of national literature. It was firmly entrenched as the pinnacle of achievement of Macedonian literature of the interwar period.

Ratsin participated in discussions on issues of tradition and innovation, the problem of artistic "truth" and the purpose of art, the nature of "bias" the correlation between ideology and artistry, the social origin of the artist and his work. Speaking in Belgrade's Umetnost i Critika ("Art and Criticism") and Nasha 
stvarnost ("Our Reality"), along with other like-minded people, he argued that literature should strive for truth. It is the basic condition of realism, which is unattainable without the connection of artistic creation with the social environment. He criticized the simplified approach of evaluating a work of art, wrote about the importance of modern poets mastering the traditions of world culture. Ratsin saw the task of art as being the depiction of the reality of national life. The close connection of social realism with spiritual tradition and national existence was, in his opinion, in the convergence of national literature with folk art. This was most fully formulated in his article Razvitak $i$ značenje jedne nove naše knjžeunosti ("The Development and Significance of Our New Literature," 1940), dedicated to the birth of literature in the national language in Macedonia. This article served as a manifesto, announcing a qualitatively new artistic phenomenon, and at the same time it was a spiritual testament of the poet, who believed that the successful development of modern realistic literature was possible only by relying on folk traditions. Ratsin called contemporary Macedonian writers the descendants of those creators who in the distant past attempted to write in the native language of the Macedonian people.

Translated by Igor Kaliganov

\section{BIBLIOGRAPHY}

Beliaeva U.D. Kocho Ratsin i rozhdenie makedonskoi proletarskoi literatury // Zarubezhnye slavianskie literatury. XX vek. Moskva, 1970. S. 369-84.

Ivanovi $R$. Poetikata na Kosta Ratsin. Skopje, 1979.

Nanevski D. Poetot Ratsin. Skopje, 1983.

Ristovski B. Kocho Ratsin. Istorisko-literaturni istrazhuvanya. Skopje, 1983.

Sheshken A.G. Makedonskaia literatura XX veka. Geneziz. Ėtapy razvitiia. Natsional'noe svoeobrazie. Moskva, 2007. S. 44-56.

Sheshken A.G. Tvorchestvo Kocho Ratsina v svete makedonskoi kul'tury perekhodnogo perioda (1920-1930-e gg.) // Slavianskij vestnik. Moskva, 2009. Vyp. 3. S. 288-302.

\section{ILLUSTRATIONS}

1. Photo of Kocho Ratsin.

2. View of Veles, 1920th. Card.

3. The cover of Kocho Ratsin's poetry collection "The White Downs."

4. Monument to Kocho Ratsin on Mount Lopushnik.

5. Monument to Kocho Ratsin in Veles.

6. Monument to Kocho Ratsin in Lazaropolis.

7. The collective of folk dance and song named after Kocho Ratsin.

8. The House-Museum of Kocho Ratsin in Veles.

9. Presentation of the diploma "Ratsin's Recognition" for the best prosaic work of 2019 to writer Venko Andonovski.

10. A postage stamp with image of Kocho Ratsin, 1983. 